will be afforded to the officers of these great estsblishments to place their talents at the service of the public :-

$$
\text { "War Department, Feb. } 17 .
$$

"Gentuemen, - I am desired by Lord Panmure to request your immediate and earnest consideration of a subject which at this moment engages his lordship's most anxious attention -namely, the best means of rendering the vast professional resources of Great Britain, and more particularly of the metropolis, available for the medical relief of the British army at the seat of war. Lord Panmure is well aware that members of the medical profession, ever forward in a cause of humanity, no less than of patriotism, would not be wanting to respond to any appeal which might be addressed to them by the Government; wut his lordship is of opinion that the present necessities of the army call for medical assistance of an order which can only be insured by selection from individuals who have already given proof of their possession of the requisite skill, and whose antecedents guarantee their experience; such individuals must be looked for first in the medical establishments of the great metropolitan hospitals.

"I am directed by Lord Panmure to request your aid and concurrence in his organization of a special civil medical staff to assist the military medical staff of the army at the seat of war. His lordship considers that this could be best effected by your selection of two or more medical gentlemen for the posts of physician and surgeon, of four or more other gentlemen of a junior standing as assistant-physicians and surgeons, and of such proportion of advanced medical pupils as you may deem necessary to perform the duty of dressers ; but his lordship considers that such an arrangement will fail to secure the services of the most highly qualified of your officers unless you can at the same time, by an internal and private arrangement of your establishment, protect the gentlemen selected from a permanent professional loss resulting from their humane exertions. This can probably be effected only by declaring that such offices as may be held by gentlemen volunteering to proceed to the seat of war on temporary furloughs from the establishments to which they belong shall not be declared vacant during their absence; but that their duties shall be provisionally performed by other gentlemen especially appointed. for the purpose, and that they shall be reinstated in suath offices on their return.

"The remuneration which Lord Panmure would propose for these officers would be that already fixed for the civil medical officers at Smyrna, which are as follow-viz., physicians and surgeons, $222 s$. per diem; assistant ditto, $215 s$. per diem. But his lordship will be ready to consider any suggestions you may desire to make on that head; and I am instructed to add, that to meet the case of gentlemen who may give up private practice to proceed to the East, it is his lordship's intention to propose that the salary to be paid by the Government shall be continued for one year from the termination of the engagement, which it is hoped will enable those who may find their private practice wholly or partly passed into other hands, to bear with less inconvenience the interval that may elapse before they can recover it.

"Lord Panmure proposes that the hospitals to be conducted by the civil staff shall be as much as possible distinct from and apart from those in charge of the military staff; nevertheless, he proposes to give local medical rank to the gentlemen so engaged.

"Lord Panmure is well aware that in the present infected state of the great hospital at Scutari a local removal of the sick is greatly to be wished. This subject presents many practical dificulties, but his attention has been given to the means of overcoming them; and he trusts that the infection in question will not remain to augment the difficulty of the duty.

"I am, gentlemen, your obedient servant,

OFFICTAL REPORT OF SIR A. MORISON, M.D., AND FORBES WINSLOW, M.D.,

IN THE CASE OF

GREENWOOD, AN ALLEGED LUNATIC.

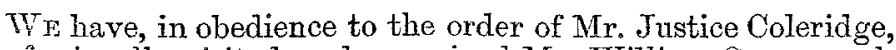
professionally visited and examined Mr. William Greenwood, of Wattey-place, Todmorden, Lancashire, now, by order of the Court, under the temporary care of Mr. Widdington, of No. 21,
St. John's Wood-road, with the view of ascertaining the state of his mind. We have had five interviews with this gentleman-viz., on the 5th, 6th, 7th, 8th, and 9th of February inst., each interview being of some duration. We have visited and examined him separately and in consultation, and have fully considered each particular symptom and state of mind represented to indicate insanity. After a careful investigation of this case, we have arrived at the following conclusions:-

Mr. William Greenwood's mind is undoubtedly enfeebled, the mental affection manifesting itself principally in loss of memory and in confused notions of the nature and extent of his property. But, in justice to Mr. Greenwood, we are bound to state, that he appears to have a right and lucid appreciation of his pecuniary position, when the particulars of his property are placed specifically and clearly before him. When asked pointedly the question as to the extent of his property, he replied, that as much of it is invested in railway shares and in land, he could not state accurately its precise amount; but he said, "If I give a guess, I should say it was $£ 65,000$," adding, " that is, money belonging to the firm." He also said that his property was principally invested in Lancashire and Yorkshire railway shares, in houses, and in land. We had several conversations with him respecting his family. He informed us, after a little hesitation, and without suggestions from others, that he had three brothers, (specifying their names, one sister, and several illegitimate children, referring particularly to Mrs. Ormerod, whom we understand to be his natural child.

Mr. Greenwood's affections appear, with one slight exception, to be quite natural. He speaks feelingly of some unhappy differences that have existed between himself and his brother Robert, whom he represents to be a man of irritable temper, and who, he says, on one occasion committed an assault upon him. We are informed that Mr. Greenwood's statement is, in point of fact, correct, he having had, before leaving home, a personal scuffle with his brother Robert. This unfortunate altercation appears to have made a strong impression upon Mr. Greenwood's naturally sensitive mind, and to have given origin to the suspicion which is said formerly to have existed, but which is now almost altogether dismissed from his mind, that Mr. Robert Greenwood would, if he had an opportunity, again attempt to injure him. We pressed him repeatedly and closely upon this point, in consequence of its having been stated, in the two medical certificates consigning Mr. Greenwood to the lunatic asylum, that he was under a delusion that his brother Robert had tried to poison him, and that he, Mr. Greenwood, being afflicted with this hallucination, had threatened to shoot him. When spoken to upon this subject, Mr. Greenwood, under the influence of strong emotions, and with great emphasis, positively denied that he had ever made such a threat. He affirmed that he had never harboured a thought of injuring his brother Robert or any of his relatives. Upon our asking him on another occasion the question, "Did you not say you would shoot your brother Robert?" he laughingly said, "Certainly not; I am not a fighting man." In answer to our question, "How did your brother attempt to injure you ?" he, after some hesitation, replied, "That is a close question. I do not wish family matters to be made public. It is a secret. I wish to live at peace with him. I do not wish to tell about it." Upon being farther pressed to explain the nature of his brother"s aqtack, he, evidently with great reluctance, said, "Well, he jumped upon me." Coupled with these remarks, Mr. Greenwood gave expression to feelings of great affection for each member of his family; but observed, that in consequence of his differences with his brother Robert, he would, if liberated from retraint, prefer residing apart fron him. When asked where he would like to live? he replied, "At the place where $I$ was born, at Askinhurst, where I have a good house. I should," he continued, "wish to live and die there." If he occupied that house, he said he should like to see his brothers frequently if they did not reside with him.

We are of opinion that Mr. Greenwood's feeling towards his brother Robert cannot be viewed in the light of an insane delusion, or as establishing morbid alienation of affection, although we think he attaches much importance to the fracas that took place between them. Mr. Greenwood is alleged to have entertained an idea that "poison" had been given to him; but this impression should be viewed in association with the fact, that for some period, as we are informed, Mr. Greenwood has suffered from derangement of the stomach and liver, accompanied by great gastric irritability. This affection exists at the present time; for during our interview with Mr. Greenwood at Wood's Hotel, Furnival's-inn, London, on Monday last, he had a violent attack of vomiting. To this morbid condition of the 
stomach and liver may, we think, in a great measure, be traced the delusion which is said to have existed at the time when the certificates were signed, that he had had administered to him something that had caused his food to disagree with him; and we are of opinion that when he is liberated from the asylum, his bind relieved of all apprehension as to any future interference with his free-agency, his general health improved, and the functions of the stomach and liver restored by appropriate medical treatment, and he has the advantage of change of air and scene, there will be no recurrence of this symptom. The idea of "poison" has not, according to our judgment, the character of a chronic and fixed insane delusion. It appears to be an evanescent impression, arising, as we conceive, from severe stomach disorder and biliary derangement, as well as from his having been frequently sick at the stomach immediately after eating. This conclusion is somewhat strengthened by the fact that occasionally we have observed an absence altogether of the idea, and it has been, and is, a question with us whether the notion has ever existed in $\mathrm{Mr}$. Greenwood's mind as a delusion, in the right acceptation of the term. In our examination of him on the $7 \mathrm{th}$, we again brought the subject prominently before him. He was asked if he had ever said that his brother Robert had attempted to poison him? He, with considerable vehemence, exclaimed, "No, no; I meant Robert used unpleasant language-poisonous language." Is it not possible that Mr. Greenwood used the word poison figuratively, not really fancying that his brother, or any one else, had seriously attempted thus to injure him?

We had several conversations with $\mathrm{Mr}$. Greenwood respecting his property, and addressed ourselves particularly to him regarding his views as to its testamentary disposition. Mr. Greenwood appears to entertain a right appreciation of the claims of consanguinity, and on more than one occasion he emphatically declared that his relations, mentioning the names of his three brothers and sister, should, to quote his own language with regard to his property, "share and share alike" after his death. But whenever we spoke to him respecting the disposition of his property, he always said it was his wish to leave some portion of it to Mrs. Ormerod, his illegitimate danghter. We are clearly of opinion that the feeling he appears to have for his brother Robert, in consequence of the assault referred to, would not induce him to alienate from him any share of the property that the brother naturally has a right to expect should be bequeathed to him at Mr. William Greenwood's decease. He repeatedly observed, that he entertained a strong affection for all his family, and, bursting into tears, said that he had no desire to live otherwise than on terms of love and amity with them. He expressed a strong wish to have an establishment of his own, and appeared to have a great horror of returning to Mr. Pindar's Asylum.

Without expressing any opinion as to the necessity of $\mathrm{Mr}$. Greenwood's original detention, or as to the treatment to which he has been subjected since his confinement in the asylum, we, after viewing the case in all its details, having a due consideration for the personal comfort of Mr. Greenwood, and a proper regard for the pecuniary interests of his family, are strongly of opinion that, although his memory is impaired, his judgment and affections are not sufficiently implicated to justify his further detention in an asylum for the insane, or his being placed elsewhere under restraint as a certified lunatic. We have no hesitation in recording it as our opinion that Mr. Greenwood, if liberated from confinement, would not prove dangerous to himself or others. We respectfully suggest that his family should take his strongly expressed wish immediately into consideration, and without any delay allow him to have a liberally organized establishment of his own, under the kind and judicious care of one of his family, or some friend in whom he has confidence. Mr. Greenwood is in a condition of mind to fully participate in all the social enjovments and comforts of life, and he should be treated with great indulgence and liberality, the whole of his income for this purpose being placed at his conmand. An occasional excursion to the seaside would greatly benefit his health, and we see no ohjection to his occasionally travelling, having due regard to the season of the year, and his physical infirmities. Under this system of treatment, his bodily and mental health would, in all probability, improve, and his mind be restored to a state of happiness and tranquillity. We are of opinion that, with Mr. Greenwood's nervous dread of being restrained amongst the insane, his compulsory return to the lunatic asylum would seriously endanger his health, and certainly shorten the duration of his life.

\section{THE WAR.}

\section{[FROM OUR SPECIAL CORRESPONDEXT.]}

CAMP Before Sebastopor, January 26th, 1855 .

THrNas go on here pretty nearly the same as usual, slow, but I trust sure. Since my last letter we have had some very severe weather, enough, if it lasted very long, to kill the fer remaining men we have left behind. Snow has been on the ground for days, and once or twice the wind from the north so high and cutting, that all who could keep in their tents did not venture to show their noses out. At present the snow is gone, and we have very fine weather-of course cold (but not more so than in England) at night, generally a sharp frost. If this weather was to last, we could live in our tents well, and sickness would doubtless decrease greatly. I am glad to see the wooden huts springing up gradually, all being for the present for the sick. The Grenadier Guards set the example. These huts are really very comfortable and warm, each capable of containing about twenty-eight men, fourteen on each side, all lying on boards that form the floor, gradually sloping down to the feet, where the floor ceases, and a space of about three feet is left for a passage. Above the heads of the men is a shelf for their mess things and water bottles, while the knapsacks and firelocks are placed still higher upon rafters. After the poor fellows had been put into them, the degree of comfort was extremely cheering, compared with the miserable tents, All seemed pleased, each man lying on a blanket and cow-hide, having two blankets to cover him, and another hide. Each man throughout the army is now to be given three blankets, and not too soon, for the nights are very cold. These cow-hides are excellent things; they are very warm-in fact, they are buffalo-skins, not cow-hides - a great difference: one covers three men. Though the men have been only a few days in these houses, many have begun to improve. As you may suppose, after the houses were put up, not a few tried to smuggle themselves into them; however, the most promising and able soon had to make way for the worst cases. Many more would soon be here, but bringing them up from Balaklava is no mean work, on account of the roads. As regards sickness, it is very great; hundreds are removed every week to Scutari, and an immense number die. Medicine seems to be of little service, and many now give but little. The men die for want of proper nourishment-for instance, a man feels ill, loses his appetite, generally suffers from diarrhcea or dysentery for some time, and reports himself to you when too weak for duty. For days you find he has not eaten his rations, not tempting to a man at all out of sorts, (pork, mostly, and biscuits.) You have then to begin on a constitution every way impaired, under every disadvantage, the patient having up to the time of your seeing him been placed in a tent, without sufficient clothing or sufficient nourishment. Now I am glad to say that the regimental surgeons do not scruple to send to the authorities for a supply of these necessaries-potted meats, soups, vegetables, fish, wine, and hoc genus omne, as we know the good folks at home will be only too willing and ready to give the unfortunate sick and wounded here all the comforts they require. With these late improvements and the wooden huts, in which I put great faith, I hope our mortality will greatly lessen.

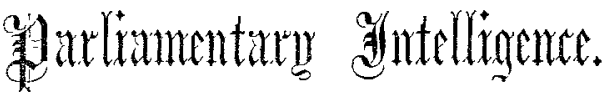

\section{HOUSE OF COMMONS.}

GRANTS FOR THE NAVAL MEDICAL SERYTCE

ON the discussion of the Navy Estimates, Mr. Grogar wished for an explanation respecting the item of $£ 1800$ for constructing Lock wards in Portsmouth Hospital, voted last year, and which did not appear to have been expended, now appearing in this year's estimate.

Sir James GraHAM, in reply, stated that the sum had not been expended, in consequence of some misunderstanding between the governors of the hospital and the Government with respect to the accommodation to be afforded; the differences having been settled, the building of the wards would be at once proceeded with.

On the vote of $£ 62,100$ for medicine and medical stores, $\mathrm{Mr}$. STAFFORD stated that, having visited the naval hospital at Therapia, he had the greatest pleasure in bearing his testimony to the efficient state of the hospital, and the excellence of the 